\title{
Poetics of Resistance in Roman Antiquity: A Reading in Neronian Prosopography
}

\author{
Emmanuel Folorunso Taiwo \\ Senior Lecturer, Department of Classics, \\ University of Ibadan, Nigeria
}

\begin{abstract}
Voices of dissent, whether verbal or written, have the historical antecedents of being symptomatic of governments characterized by oppressive policies and brutal force. In both ancient and contemporary climes, resistance poetry assumed different meanings in different creative contexts and academic disciplines. We have witnessed dissident activities transformed beyond linguistics, into armed struggle, against the individual or persons in power. During the Julio-Claudian dynasty, particularly, the Neronian Principate engendered poetics of resistance, due to its repressive policies. This paper attempts to examine the cadence of resistance poetry during this period relative to the prosopography of Emperor Nero (AD 54-65).
\end{abstract}

Keywords: poetics, resistance, Roman antiquity, Julio-Claudian, Emperor Nero

Writers in classical antiquity were adroit at depicting the adaptations and elusiveness necessary for survival under the pressures of living in a tyrannical regime. Yet their themes expand well beyond the parameters of political repression to address the moral contradictions and fickleness of the despot's personality. Emperor Nero was one such tyrant whose internal compulsions combined with some external forces to buffet the fluidity of his identity. In the words of Jackson and Rosberg, "in a tyranny not only legal but also all moral constraints on the exercise of power are absent, with the consequence that power is exercised in a completely arbitrary fashion according to impulses of the ruler and his agents" (1982, p. 9). Over the years, scholars of ancient history, especially of classical Rome, have variously seen Nero's reign as portraying the greatest brutality among the Julio-Claudian emperors. But then Gaius, the second of Augustus' successors, was a wild tyrant, and aided by an equally wild temperament, he renounced all his promises of deferring to the senate and embarked on an experiment in oriental despotism ${ }^{1}$.

\footnotetext{
1 This experiment was informed by his patronage of Egyptian and other Eastern kings and princes, whose advice he sought. DIO CASS. Lix. 28.1ff.
} 
Nero and Gaius shared tastes in the arts, chariot racing and a thirst for the brutality of gladiatorial shows. But while Gaius' tyrannical tendency was manifested in his adaption of oriental mentality in absolutism; a strong belief in his becoming the first mortal god, Nero's was in the pursuit of what he saw as the manifestation of the superiority of his position as princeps, along with its attendant beneficence on his subjects. This beneficence was unfortunately his tyrannical promotion of a pseudo-cultural excellence in Greek arts.

Nero had displayed to a damning extent his despotic power by promoting his poor taste in literature and theatrical shows in such a way that tended to stifle the decency of the Roman people. This drew the resentment of no less a fire-band writer/critic than Flaccus Persius (AD 34-62), an Etruscan knight from a well connected family. He lived and wrote under the emperorship of Nero and was a contemporary of M. Annaeus Lucanus/Lucan, another vicious critic of Emperor Nero. Along with others, they systematically condemned the Neronian principate and its idiosyncrasy and culture of pseudo- learning, sensual perversion, and incontinence.

Persius wrote six satires, which form a total of 650 hexameters of fourteen choliambic verses with a brief preface, during his short but sheltered life. His stoic leaning had considerable influence on his satires, which have been variously seen as obscure, difficult in style, but as critical of Emperor Nero. The satires of Persius have been aptly described by Villeneuve (1918), ${ }^{2}$ as a historian diatribe transformed by stoic rhetoric. In Satire 1, Persius criticizes the activities of pseudo-poets and the contemporary fashion of admiring elegant but unrealistic poetry. The leitmotif of this satire is the condemnation of Nero's taste in poetry and his self-acclaimed status as the champion of the arts. And in this imagined dialogue with a friend, Persius judges literary taste as symptomatic of contemporary decay in the society:

Inde uaporata lector mihi ferueataure, non hic qui in crepidas Graicorum ludere gestit sordidus et lusco qui possit dicere 'lusce', sese aliquem credens Italo quod honore supinus fregerit heminas Arretiaedilis iniquas, nec quia baconumeros et secto in puluere metas scitrisisse uafer, multum gaudere paratus si cynico barbam petulans non ariauellat. his mane edictum, post prandial Callirhoen do. (Sat, 1.126-134)

2 F. Villeneuve, Persius satires. The "evidence" comes from Ancient life of Persius, but sometimes ancient biographies are not always reliable. 
I want a reader with his ears well steamed by that comic vinegar, not the lout who is eager to jeer at Greek-style sandals, and is willing to shout 'Hey one-eye!' at a man with that affliction, who thinks he's somebody just because as Aedile at Arezzo he has smashed a few short measures with full municipal pomp, nor the witty fellow who sniggers on seeing cones and numbers traced in the sand of the abacus, and as is vastly amused if a Nones-girl cheekily pulls a philosopher's beard. For them I suggest the law reports in the morning, and Calliroe after launch. (Rudd, 126-134)

In Satire 3, he sermonizes on the damage done to depraved souls by corruption and vice, while in satire 4, he gives candid advice to a young statesman, who could easily have swapped places with Nero, to disregard public accolades and pursue virtues by examining his own character. One wonders whose character needed re-examination, but Nero's. In essence, Persius' satirical irony is critical of the activities of the depraved emperor, Nero, whose warped idiosyncrasy is kindled by public accolades, as indicated in the following lines from Persius (Sat.1.69-71):

ecce modo heroassensusadferevidemus

nugarisolitosgraece, necponerelucum

artifices ne crus saturumlaudare,

behold; so we now see heroics produced by individuals

who are accustomed to frivolous Greek verses, me who have not art enough to describe a grove, or praise the abundance of country life (trans. ours)

He begins the first satire with a vitriolic criticism of the foppery and ostentations of public recitation by authors who excite the passion of a depraved audience with their licentious verses.

'turpe et miserabile.' quare?

Ne mihi Polydamas et Troiades Labeonem

praetulerint? nugae. non, si quid turbida Roma eleuet, accedas

examen uein probum in illa

castigestrutina necte quaesiueris extra (3-7) 
'Disgraceful! And pathetic!' but why?

are you worried in case 'Polydamas and the Trojan ladies' prefer

Labeo to me? What the hell? If woolly old Rome attaches

no weight to a piece of work, don't you step in to correct

the faulty tongue on her balance. Ask no one's view but your own (Rudd, 3-7)

Though this is done through pseudonyms, the tone may have been modulated by Cornutus, his famous philosopher/mentor, who was reported to have rewritten some of the works considered to be too vitriolic in their attack of the emperor. In addition, this may have been intended to avoid the anger of the emperor ${ }^{3}$.

Modern scholars, such as Grimes (1972, p.25) have absolved Persius of any direct political allusions to the emperor, arguing that even though there is a preponderance of the sermonizing, defining characteristic of the stoic opposition to Nero during his period, there was no political depth to the satires. Citing Dio's account of his revered teacher, Cornutus, who was exiled in 65 BCE for speaking freely, Grimes continues: "Yet in spite of such committed company, Persius makes no political criticism or allusions in his Satires and avoids all references to specific contemporary events, institutions and celebrities" $(1972,26)$.

Although Grimes' position merits some consideration, it is still possible to state that Persuis' preoccupation was philosophical as he was better disposed to attacking those vices which he saw as directly akin to a violation of virtue, or the victorious way of life. In essence, therefore, he would have preferred the sanctimonious approach which satire provided to Lucan's frontal attack. While Persius was moved to lampoon the contemptible pretensions of literature, others were disposed to write against Nero's tyrannical philhellenic predisposition.

Such writers as the famous historian, Tacitus in his Annals invariably saw the development as being responsible for the decline in Roman morals. He is quick to link the decline in morals, to the flourishing of drama in Rome. In his view, such shows were areas through which the worst foreign influences flowed into Rome. Tacitus has this to say:

\section{Ceterum abolitos paulatim patrios mores}

Funditus everti per accitam lasciviam, ut quod usqwam corrumpi et corrumpere queat, inurbevisatur, degeneret questudiis externis inventus,

\footnotetext{
3 The dimension of poetry in satire one is quite in the Neronian style and the reference to Midas (Sat.1.119-21) has also been said to allude to Nero.
} 
gymnasia et ostia et turpis amores execersendo.

(Tac.Ann, xiv 20)

Our ancestral morals, already in a state of gradual deterioration, have been quite overturned by this imported laxity. It causes everything potentially corrupting or corruptible to be on show in the capital. Foreign influence demoralizes our young men, making them pursuers of idleness, gymnastics and shameful love affairs (trans. Green P.).

The audience is not excited by the artistry of the dramatist, but rather interested in the lurid spectacles of the shows (Bieber, 1961, p. 28). Hence, Tacitus' use of the Latin term "accitam," while apt in conveying the sense of "imported from outside," also expresses the idea of "self-inflicted". Therefore, it may have been the susceptibility of the lowest elements in the society to "studia externa" - "outside influences," that drew the anger of Tacitus and others in the upper rung of the Roman society and caused them to speak and write against Nero's frivolities. Indeed Persius in his Sat 1.17-23 presents a graphic picture of contemporary literary stylistic depravity. He denounces the content and manner of presentation to the audience:

\section{liquido cum plasmateguttur}

mobile conlueris, patranti fractus ocello.

Tunc neque more probo uideas necuoceserena

Ingenti strepidare Titos, cum carmina lumbum

intrant et tremulos calpuntur ubi intima uersu.

tun, uetule, auriculis alienis colligisescas,

ariculis quibus et dicas cuteperditus 'ohe'? (17-23)

Rinsing your supple throat with a clear preparatory warble, your eyes swooning in ecstasy. Then, what a sight!

The mighty sons of Rome in a dither, losing control of voice and movement as the quivering strains steal under the spine and scratch the secret passage. You old fraud- collecting tidbits for other men's earsears which will puff your skin out of shape until you cry 'whoa there'(trans. Rudd, 1978)

Without doubt, imagery of effeminacy is conveyed by the reciter's voice modulation and the betrayal of a lecherous but unmanly glint in his eyes as he recites the lines. The younger Pliny (AD 61 or 62-113), who may have remembered as a child the 
activities of Nero, likewise spoke and wrote against the society which tended to become coarser through theatrical and circus shows. He wrote ten books of letters on different subjects in relatively straightforward prose, and poetry, a few examples of which are extant. The subjects of his writings include eulogies of writers, such as Martial, and the heroism of Arria, the wife of Thrasea Paetus. In his Panegyricus (54.1), Pliny is critical of the audience's enthusiasm for Nero's theatrical presentation.

Martial, another poet of a later period, expressed disdain for the ludi scaenici. This disdain by the upper class may have encouraged private theatrical performances for a select audience by some in this class. Martial, however, was abject in his flattery of Domitian. Pearse (as translator of Martial's Epigramata) observes,

Here, where the starry Colossus surveys the skies from nearer point than we, and where lofty scaffoldings now rise the midst of the street, the detested halls of a cruel king lately glistened, and one single mansion began to occupy the whole space of the city. Here, where the venerable mass of the far-seen Amphitheatre now rises, were the ponds of Nero. Here, where we gaze with admiration at the Thermae, a boon so suddenly bestowed, a proud lawn had deprived poor wretches of their homes. Where the Claudian portico now throws its wide-spreading shadows, was the last remnant of a felling court. Rome has been restored to herself, and what were formerly the delights of the master, are now, under thy rule, Caesar, those of the people (2008, pp.25-26).

However, in spite of this disgust felt by the Roman nobility for actors, accounts have it that some members of the elite were so fascinated by the privilege, that they shamelessly appeared on stage ${ }^{4}$, even as gladiators (Barton, 1989, p. 72).

Juvenal does not hide his indignation at this degradation of Roman mores. In Sat 8.193, he laments the appearance of some noble families on stage; "nullo cogente Nerone" (without a Nero to enforce it). Roman society in general viewed the stage and other public appearances of that nature as totally against proper etiquette. This is evident from an order by Tiberius banning senators and equestrians from associating with these in fames (Tac. Ann, 1.77).

However, with the accession of Nero to the throne, this tendency of the elite class received imperial blessings. Besides compelling individuals of this class, Nero also appeared on stage himself. Indeed, when Emperor Nero became an actor, appearance was mistaken for reality. This gesture single-handedly put him above the social constraint, which bound the rest of the Roman society. Seutonius remarks: 


\section{Tragoedias quoque cantavit \\ Personatus heroum \\ deorumque, item \\ heroidum ac dearum}

He also wore a mask and sang tragedies

in the character of gods and heroes

and even heroines and goddesses. (Suet. Nero, xxi.3)

Nicolet (1980) recalls that Roman theatre audiences in the last century of the republic were politicized to a remarkable extent (pp. 10-15). Thus, an actor, whether of comedy or tragedy, made political allusions through his lines directed at the contemporary political mood. Therefore, the audience would have been highly sensitive to lines capable of multiple interpretations.

Years later, during the reign of Trajan, Pliny the Younger, in a speech in praise of the optimus princeps, was to express horror at the imperator scaenicus Tacitus, whose works were critical of the tyranny of the Julio-Claudian emperors, especially Nero. Pliny the Younger also recorded a story about a young soldier, who in disgust decided to join the Pisonian conspiracy against the emperor (Ann, xv.67):

\section{Odisse coepi, postquam}

Parricida martris et uxoris, auriga et histrio et incendarius extitisti.

I began hating you when you killed your mother and wife and became a charioteer, actor and incendiary (Grant, 1975, p. 61, Trans.)

Such were the feelings of disgust expressed by these writers as shown in their works during this period, most of whom adopted a publish-and-be-damned attitude which emboldened their resolve even in the face of Nero's no-nonsense stance against literary rivalry.

However, a writer like Petronius was more discreet since he had the advantage of maturity on his side. Seneca, though a dissenting voice, clearly had no proclivity for confrontation with the emperor. He thus concealed his works behind the screen of philosophy. Juvenal was another fire-brand critic of the Neronian regime, known for his bitter criticism against the society and certain individuals chose, however to vent his 
indignation on the "long dead." These writers suffered one form of repression or another, which shaped the literature of the period.

One author of this period, who has been identified as the most voluble critic of Nero, was Lucan/M. Annaeus Lucanus (AD 39-65) ${ }^{5}$, born of an eminent pedigree at Corduba in Spain. He was a cousin to Seneca the Elder, and he became Nero's teacher. Lucan had his education, just like Persius, in Rome under the famous stoic philosopher Cornutus. He was for several years a prominent poet in Nero's court. Nonetheless, the friendship between the emperor and Lucan turned sour and in AD 65, Lucan joined Calpurnius Piso's conspiracy to overthrow Nero. When ordered to commit suicide, Lucan recited several lines of his poetry before death (probably Book III, 1. 700-712). An antiimperialist writer, Lucan made it clear in the opening lines of his De Bello Civili, that freedom and true Roman spirit died with Pompey at Pharsalus. This work, the only one extant of all his literary efforts, was a celebration of Pompey as the beacon of the old republican freedom. Based on the struggle between Pompey and Caesar at the battle of Pharsalus, his epic poem laments the loss of freedom during Caesar's reign ${ }^{6}$. It should, however, be noted that even though his account is not scrupulously accurate, its attraction lies in the poetic aesthetics as a work of literature, which endeared it to the medieval and renaissance poets.

Lucan's De Bello Civili also lends itself to a political interpretation owing to the nature of his involvement in dissident activities during Nero's reign. Early in the opening passages (1.30-40), he laments the destructiveness of war and celebrates the accession of the emperor Nero as portending good prospects for Rome and for the restoration of republicanism.

non tu, Pyrrhe ferox, nec tantis cladibus auctor

Poenuserit: nulli penitus descendere ferro

contigit; alta sedent ciuilis uolnera dextrae.

quod si non aliam uenturo fata Neroni

inuenereu iam magno que aeterna parantur

regna deis caelumque suo seruire Tonanti

nonnisi saeuorum potuit post bella gigantum, iam nihil, o superi, querimur; scelera ipsa nefasque

hac mercede placent. Diros Pharsalia campos

Inpleat et poenis aturentur sanguine manes;

neither you savage Pyrrhus nor Hannibal ever caused such havoc:

5 Pliny, Pan. 46.4

6 Lucan, Phars. VII. 
none of the other antagonists could strike thus deep;

but civil strife alone dealt the fatal

Wound and left Death behind. Yet if the fates could

find no other way to prepare

For Nero's coming, nor the gods with ease

Gain thrones in heaven; and if the thunderer

could not prevail till the giant's war was done,

then we complain no more against the gods

even such atrocities and crimes are not too high a price to pay,

let Pharsalia's fields be crowded with our dead (trans. ours).

Tyranny in Lucan's view was triumphant at Pharsalia. Why then did Rome ever know freedom, if she was to lose it? Surely, the gods' apathy had led through civil warfare to the creation of new deities and a new religion in emperor worship. These sentiments of Lucan in the seventh book provide evidence of the change in AD 65. Additional episodes are contained in the three books, which he probably wrote between the years AD 62 and AD 63.

This change of attitude mentioned above is given further credence in a tradition by Vacca's life, written about four centuries later. The account has it that Nero did reserve the Latin verse prize at the Neronia for himself. Having become jealous and indignant when the audience applauded Lucan's Orpheus and Eurydice somewhat too enthusiastically, he forbade him from giving poetry recitals even in private. This animosity, which also led to the banning of Lucan's poetry and the termination of his senatorial career, has been emphasized in Tacitus' account in the Annals and adduced as Lucan's personal reason for joining the Pisonian conspiracy (Ann. XV 49. 3).

In addition, the view that Lucan's Bellum Civile was politically motivated receives enough backing from the tradition on Lucan's involvement in the Pisonian conspiracy, as well as from all the historical sources in support of the rupture in relationship. Besides, the Bellum Civile betrays the indignation of a republican activist with his furious fervour for the old republic. In addition, there is ascription by Johnson (1987) of a dual image to Pompey as a symbol of failed hopes and chances nearly grasped but subsequently lost (p.145).

Indeed another position, which sounds equally convincing, is that of Rudich (1997) that the change is reflected in Lucan's assuming a pro-Pompeian stand. The ban on publishing and reciting, he points out, drove him underground allowing him to jettison the mask of pretence (p. 85). Yet the dissenting voice of Kleijwegt [1998] points to the dubious integrity of the historical source material, contending that there are no ancient parallels for the combination of political poetry and action along the lines of the ideological message of the Bellum Civile. Therefore, it would be risky combining both 
elements. But from the arguments above, an outright political reading would not be quite apt, since it is the view of Tacitus elsewhere ${ }^{7}$ that restoring the old republic was not the objective of the conspiracy. In other words, assessments of Lucan's writing under the Neronian regime should be accepted with cautious assertion. The above notwithstanding, extant accounts of the reign of Nero indicate that literature critical of the tyranny of the emperor was sustained by a small circle of the elite who were social and political stakeholders in the empire. They may not have wanted a restoration of the old republic, but they were adversely affected socially and politically by Nero's style of governance.

Gaius Petronius Arbiter, the generally acclaimed author of the Satyricon, was also a member of Nero's circle. He was a prominent figure in the Neronian government (this may have precipitated his disaffection towards Nero). According to Tacitus ${ }^{8}$, Petronius "idled into fame." Unlike most of his contemporaries who trod the way to ruin, he was never regarded as a debauchee or wastrel, but as an accomplished artist luxu eruditus. And for this same reason, he incurred the jealous anger of Tigellinus and was implicated in the Pisonian conspiracy. Petronius Arbiter is reported to have lived under the reign of Claudius (AD 41-54) and died under Nero (AD 54-65). His work did not differentiate between sexual immorality and sumptuary excesses. Rather licentia and luxuria, constituted themes for his attacks on particular individuals. It is said that he shocked Nero, when, on his deathbed, he sent him a "chronique scandaleuse," a comprehensive list of the emperor's sexual diversions with the names of members of both sexes. The Satyricon shows Petronius as a critical observer of Neronian society. This enabled him to develop a picaresque tradition, which was also critical of the incontinentia of Nero. His themes invoke amusing parallels from Greek literature and issues of interest around him. These issues have by the consensus of modern writers, such as Edwards (1996), Green (1967); Rudich (1987) among others, been seen as satirical of Nero.

Written between the years AD 63 and AD 66 the work covered the active years of Nero's frivolities. Boissier (2012) believes that the work was composed for court entertainment and, therefore, would be better suited for recitation. However, because of the allusions contained therein, the recitation may have been restricted to his circle of trusted friends. These may have been the same friends, as those with whom he indulged in "light poetry and sportive lines" on his deathbed. From our reading of the Satyricon, we cannot but shudder at the realism of the "chronique scandaleuse," which Petronius may have hurled at the despot.

A particularly revealing parallel is the Cena Trimalchionis (Trimalchio's dinner party), an extended episode in the Satyricon which pokes fun at an extravagant dinner-

\footnotetext{
7 TAC. Ann. XVI, p. 18.

8 TAC. Ann. XVI, p. 19.

9 TAC. Ann. XVI, p. 19
} 
party host. This episode is replete with characters alluding not only to the activities of Nero, but also providing a vivid picture in classical literature of the social life of this period. Here the major character, Trimalchio, is portrayed as a garrulous bore, a haughty master, and a pseudo-intellectual.

These traits incidentally closely portray the idiosyncrasies of the depraved Nero, who could hardly have failed to notice them. This is not to say that there were no other morally disreputable individuals in Neronian society. There were also the nouveaux riches freedmen, and other collaborators of the emperor whose activities the character of Trimalchio appears to represent vividly. Apart from the character of Trimalchio and others of the same caliber in the Satyricon, Petronius also used low characters as personae for his moralizing speeches ${ }^{10}$. One such character is made to quote a part of a poem, which includes numerous topics on moralizing rhetoric. In addition, Petronius uses a debauched, bogus philosopher Eumolpus in Satyricon (88), to attack moral decadence in Roman society. The recourse to this technique by Petronius illustrates Perry's (1967) assertion that the satirist's use of this literary style is basically a function of the circumstances under which he wrote (p. 31). Since he was close to Nero, he had to disguise his intent by assuming a smokescreen. To this end, he drew parallels from low and base life styles in Rome. Edwards (1966) corroborates this style of writing when he notes that the Romans viewed luxury and lust as cognate vices so that those prone to sexual temptations would likewise succumb to excessive appetite for food, drink, and material possessions. Such reasoning may have prompted Petronius' indirect attacks on Nero's incontientia through his portrayal of Trimalchio. Petronius was, after all, a writer of achievement and standing in the Neronian period. A close study of his works brings to our attention the various verse passages, which appear critical of contemporary versifiers: his didactic lines through Agamemnon on "The Training of an Orator", Eumolpus' lambics on "The sack of Troy." Both compositions reveal the futility of attempting to equal the Virgilian feat. But then his use of the personae further illustrates Perry's points.

The circumstance of Seneca's literary production is one that has provoked different feelings among modern commentators. In the words of Duff (1936), few philosophers are more vulnerable than the stoic who amassed wealth and the moralist who drafted exculpatory orations to be delivered by a "tyrant." And so, modern commentators have invariably frowned upon his bitter invective against a deceased ruler in the Apocolocyntosis. However, we must bear in mind that Seneca's lampoons of Nero were based on his experiences while in the emperor's service. Nonetheless, Seneca must not be judged only by his ambivalence, for we must also realize that he was no exception to the corrupt tendencies of individuals in the imperial court, according to Pliny ${ }^{11}$.

\footnotetext{
10 TAC. Ann. XVI, p.19.
}

11 Pliny (EP. V.111) p. 79, 2. 


\section{Conclusion}

Emperor Nero, who was born into the Roman imperial household of the JulioClaudian dynasty, was notorious for his tyrannical tendencies. The prosopography of the Julio-Claudians thrived on its notoriety. Emperor Nero naturally, exhibited these traits when he became Princeps. However, there were also some extraneous factors that encouraged despotism in him. These factors include his mother, his mentor and teacherSeneca, and his other advisers. Indeed, his reign was so repressive that it drove all voices of dissent underground. Little wonder then that the temperament of literature during this period was invariably determined by the condition under which writers found themselves. In other words, the kind of literature that flourished during the reign of Emperor Nero was conditioned by the tyrannical atmosphere, which prevailed then. 


\section{References}

Barton, G. (1989). The scandal of the arena, London, UK: Oxford University Press.

Bieber, M. (1961). The history of Greek and Roman theatre. Princeton, NJ: Princeton University Press.

Boissier, G. (2012). Republicanism during early Roman Empire. (S. Wilkinson, Trans).

London, UK: Continuum International Publishing Group. (Original work published 1906)

Bramble, J. C. (1974). Persius and the programmatic satire, Cambridge, UK: Cambridge University Press.

Brunt, P. A. (1983). Princeps and equites. The Journal of Roman Studies, 73, 4275.

Duff, J. D. (1936). Roman satire: Its outlook on social life. Berkeley, CA: University of California Press.

Edwards, E. (1996). The politics of immorality in ancient Rome. Cambridge, UK: Cambridge University Press.

Grant, M. (1961). The annals of imperial Rome. London, UK: Penguin Books.

Green, P. (1989). Juvenal revisited. Grand Street, 9, 240-254.

Jackson, R. H., \& Rosberg, C. G. (1982). Why Africa's weak states persist: The empirical and the juridical in statehood. World Politics, 35, 1-24.

Johnson, W.R. (1987). Momentary monsters: Lucan and his heroes. Ithaca, NY: Cornell University Press.

Juvenal. (1974). Juvenal. The sixteen satires. (P. Green, Trans.). London, UK: Penguin Books. (Original work published 1896)

Kleijwegt, M. (1998). Ideology in cold blood: A reading of Lucan's civil war. Scholia, 7, 126-132.

Lucan, A. (1957). Pharsalia. (R. Graves Trans.). Baltimore, MD: Penguin Books. (Original work published 1897)

Martial, A. Epigramata (2008). (R. Pearse, Trans.). London, UK: Ipswich.

Nicolet, C. (1980). The world of the citizens in republican Rome. (P. S. Falla, Trans.) London, UK: Batsford Academic and Educational. (Original work published 1930)

Perry, B. C. (1967). Petronius and comic romances. Berkley, CA: University of California Press.

Petronius, S. (1987). The Satyricon. (M. Heseltine \& J. Rouse, Trans.). Cambridge, MA: Harvard University Press. (Original work published 1931)

Rudd, N. (1986). Themes in Roman satire. Norman, OK: University of Oklahoma Press.

Rudich, V. (1987). Dissident literature under Nero. London, UK: Routledge.

Sherwin-White, A. N. (1966). The letters of Pliny: A historical and social commentary (Epistulae, Panegyricus of Pliny the Younger). Oxford, UK: Oxford University Press. 
Taiwo, E. F./ Legon Journal of the Humanities 25 (2014) 23-36

Tacitus. (1975). The annals of imperial Rome. (M. Grant, Trans.). London, UK: Penguin Books. (Original work published 1955)

Villeneuve, F. (1918). Persius'satire. Paris: Hachette. 